\title{
FAKTOR-FAKTOR YANG BERHUBUNGAN DENGAN KEJADIAN RAWAT ULANG PASIEN PENYAKIT JANTUNG KORONER DI RUANG JANTUNG RSU dr. H. ABDUL MOELOEK PROVINSI LAMPUNG
}

\author{
Dwi Amalia Anggraeini ${ }^{1}$, Septi Kurniasari ${ }^{2}$ \\ ${ }^{1}$ RS. Pertamina Bintang Amin B.Lampung, ${ }^{2}$ RSU dr. H. Abdul Moeloek Prov. Lampung \\ Email: dwiamalia.anggraeini@yahoo.co.id
}

\begin{abstract}
Factors Related with Incidence of Rehospitalization Patients with Coronary Heart Disease in The Heart Room RSUD dr. H. Abdul Moeloek Lampung Province. Rehospitalization became one of the factors that determine the prognosis of coronary heart disease (CHD). Factors related with incidence rehospitalization in CHD patients among others dietary adherence, medication therapy adherence, the adequacy of activities and family support. This research was to determine factors related with rehospitalization of CHD patients in the heart room RSUD Dr. H. Abdul Moeloek, Lampung Province, 2016. This research was quantitatif with analytical method and design with cross sectional approach. Population were all patients with coronary heart disease in the heart room RSUD Dr. H. Abdul Moeloek, Lampung Province, period January-April 2016, as many as 84 people, with sample were 46 people, technic purposive sampling. Analysis bivariate were used chi square test. The result showed that were significant correlation between of physical activity with $\mathrm{p}$-value 0,013 , dietary adherence with $\mathrm{p}$-value 0,040 , family support with $\mathrm{p}$-value 0,016 and adherence therapy program with $p$-value 0,025 with incidence rehospitalisation.
\end{abstract}

Keywords: Coronary heart, Incidence, Rehospitalization

\begin{abstract}
Abstrak: Faktor-faktor yang Berhubungan dengan Kejadian Rawat Ulang Pasien Penyakit Jantung Koroner di Ruang Jantung RSU dr. H. Abdul Moeloek Provinsi Lampung. Rehospitalisasi menjadi salah satu faktor yang menentukan prognosis penyakit jantung koroner (PJK). Faktor-faktor yang berhubungan dengan kejadian rawat inap ulang pada pasien PJK antara lain kepatuhan diet, kepatuhan terapi pengobatan, kecukupan aktivitas dan dukungan keluarga. Tujuan penelitian untuk mengetahui faktor-faktor yang berhubungan dengan kejadian rawat ulang pasien penyakit jantung koroner di ruang jantung RSUD Dr. Hi. Abdul Moeloek Provinsi Lampung Tahun 2016. Jenis penelitian adalah kuantitatif dengan metode analitik dan desain cross sectional. Populasi penelitian, semua pasien penyakit jantung koroner di Ruang Jantung RSUD Dr. Hi. Abdul Moeloek Provinsi Lampung periode Januari-April 2016 sebanyak 84 orang, dengan sampel 46 orang, diambil dengan technic purposive sampling. Analisis bivariat menggunakan uji chi square dengan menetapkan 95\% CI dan $\alpha=0,05$. Hasil penelitian, menunjukan bahwa ada hubungan yang signifikan antara aktivitas fisik p-value 0,013, kepatuhan diet p-value 0,040, dukungan keluarga $p$-value 0,016 dan kepatuhan program terapi $p$-value 0,025 dengan kejadian rawat ulang. Saran, petugas kesehatan agar memberikan informasi kepada pasien dan keluarga tentang aktivitas fisik, kepatuhan diet, kepatuhan program terapi, dukungan keluarga hal tersebut dapat mempengaruhi kejadian rawat ulang sebelum pasien pulang kerumah dengan begitu diharapkan dapat meningkatkan kesembuhan pasien dan mencegah kejadian rawat ulang.
\end{abstract}

Kata kunci: Jantung koroner, Kejadian, Rawat ulang

Penyakit jantung koroner merupakan penyakit yang berkaitan dengan kerusakan pada arteri coroner seperti angina pectoris dan infark miokard (Udjianti, 2010). Penyakit ini menjadi pembunuh manusia nomor satu didunia.

Rehospitalisasi menjadi salah satu faktor yang menentukan prognosis penyakit tersebut. Pasien yang mengalami rehospitalisasi akan memiliki afek atau dampak yaitu sekitar 50\% meninggal pada 6 bulan setelah rehospitalisasi dan 25-35\% meninggal pada 12 bulan setelah rehospitalisasi (AHA, 2014).

Berdasarkan data rekam medik tahun 2015, kasus seluruh penyakit jantung yang dirawat di ruang jantung RSUD dr. H. Abdul Moloek Provinsi Lampung 960 kasus ((penderita jantung koroner 359 orang) (55\%)) merupakan pasien yang mengalami kekambuhan penyakit jantung koroner. Sedang pada tahun 2014 kasus seluruh penyakit jantung yang dirawat di ruang jantung 
adalah 740 kasus dengan penderita penyakit jantung koroner sendiri 209 orang, 46\% merupakan pasien yang mengalami kekambuhan jantung koroner. Hasil pra-survey di Rumah Sakit dr. H. Abdul Moeloek periode JanuariApril didapatkan data 84 pasien PJK 22\% merupakan pasien rawat ulang.

Hasil wawancara terhadap 10 orang pasien PJK yang dirawat diruang jantung didapatkan 3 orang (30\%) mengatakan tidak mematuhi diet yang dianjurkan, 2 orang (20\%) jarang melakukan aktivitas fisik, lebih banyak diam dan santai, 2 orang (20\%) tidak patuh terhadap program terapi dan 3 orang (30\%) kurang mendapat dukungan dari keluarga.

Berdasarkan fenomena dan data diatas, maka penulis tertarik untuk melakukan penelitian tentang "Faktor-faktor yang berhubungan dengan kejadian rawat ulang pasien penyakit jantung koroner di Ruang Jantung RSU dr. H. Abdul Moeloek Provinsi Lampung Tahun 2016".

\section{METODE PENELITIAN}

Jenis penelitian ini adalah kuantitatif. Desain penelitian analitik dengan pendekatan cross sectional.. Penelitian dilaksanakan tanggal 21 Juni 2016 sampai tanggal 31 Juli 2016 di Ruang Jantung Rumah Sakit Umum Daerah dr. H. Abdul Moloek Provinsi Lampung.

Populasi penelitian, semua pasien penyakit jantung koroner di Ruang Jantung RSUD Dr. Hi. Abdul Moeloek Provinsi Lampung periode Januari-April 2016 (84 orang).

Jumlah sampel 46 orang, diambil dengan teknik purposive sampling. Kriteria sampel adalah: laki-laki atau perempuan yang didiagnosis sakit jantung koroner di Ruang Jantung RSUD dr. H. Abdul Moeloek Provinsi Lampung tahun 2016, pernah dirawat sebelumnya dengan penyakit jantung koroner dan bersedia menjadi responden.

\section{HASIL}

\section{A. ANALISIS UNIVARIAT}

Tabel 1. Distribusi Frekuensi Berdasarkan Aktivitas Fisik, Kepatuhan Diet, Dukungan Keluarga dan Kepatuhan Program Terapi dan Kejadian Rawat Ulang

\begin{tabular}{|c|c|c|}
\hline Variabel & Frekuensi & $\%$ \\
\hline \multicolumn{3}{|l|}{ Aktivitas Fisik } \\
\hline Melakukan & 27 & 58,7 \\
\hline Tdk melakukan & 19 & 41,3 \\
\hline \multicolumn{3}{|l|}{ Kepatuhan Diet } \\
\hline Patuh & 30 & 65,2 \\
\hline Tdk patuh & 16 & 34,8 \\
\hline \multicolumn{3}{|c|}{ Dukungan Keluarga } \\
\hline Baik & 29 & 63,0 \\
\hline Kurang baik & 17 & 37,0 \\
\hline \multicolumn{3}{|c|}{ Kepatuhan Program Terapi } \\
\hline Patuh & 26 & 56,5 \\
\hline Tdk patuh & 20 & 43,5 \\
\hline \multicolumn{3}{|c|}{ Kejadian Rawat Ulang } \\
\hline Ke 2 kali & 28 & 60,9 \\
\hline$\geq 2$ kali & 18 & 39,1 \\
\hline Jumlah & 46 & 100,0 \\
\hline
\end{tabular}

Berdasarkan tabel 1 diketahui distribusi frekuensi dari 46 responden, sebagian besar $(58,7 \%)$ melakukan aktivitas fisik, sebagian besar patuh $(65,2 \%)$, sebagian besar responden memiliki dukungan keluarga yang baik $(63,0 \%)$ dan sebagian besar responden patuh menjalani program terapi $(56,5 \%)$, serta sebagian besar pasien mengalami rawat ulang yang ke-2 kali yaitu sebanyak 28 orang $(60,9 \%)$.

\section{B. ANALISIS BIVARIAT}

Berdasarkan tabel 2 diketahui dari 27 responden yang melakukan aktivitas fisik, 21 responden $(77,8 \%)$ dirawat untuk ke-2 kali dan 6 responden $(22,2 \%)$ dirawat lebih dari 2 kali. Sedangkan dari 19 responden yang tidak melakukan aktivitas fisik ada 7 responden $(36,8 \%)$ dirawat untuk yang ke-2 kali dan 12 responden $(63,2 \%)$ dirawat lebih dari 2 kali. 
Tabel 2. Hubungan Aktivitas Fisik, Kepatuhan Diet, Dukungan Keluarga dan Kepatuhan Program Terapi dengan Kejadian Rawat Ulang

\begin{tabular}{|c|c|c|c|c|c|c|}
\hline \multirow{3}{*}{ Variabel } & \multicolumn{4}{|c|}{ Rawat Ulang } & \multirow{2}{*}{\multicolumn{2}{|c|}{ Total }} \\
\hline & \multicolumn{2}{|c|}{ Ke 2 kali } & \multicolumn{2}{|c|}{$\geq 2$ kali } & & \\
\hline & $\mathbf{n}$ & $\%$ & $\mathbf{n}$ & $\%$ & $\mathbf{n}$ & $\%$ \\
\hline \multicolumn{7}{|l|}{ Aktifitas Fisik } \\
\hline Melakukan & 21 & 77,8 & 6 & 22,2 & 27 & 100 \\
\hline Tdk Melakukan & 7 & 36,8 & 12 & 63,2 & & 100 \\
\hline \multicolumn{7}{|c|}{$p$-value $=0,013 ;$ OR CI 95\% $=6,00$} \\
\hline \multicolumn{7}{|c|}{ Kepatuhan Diet } \\
\hline Patuh & 22 & 73,3 & 8 & 26,7 & 30 & 100 \\
\hline Tidak Patuh & 6 & 37,5 & 10 & 62,5 & 16 & 100 \\
\hline \multicolumn{7}{|c|}{$p$-value $=0,040 ;$ OR CI $95 \%=4,58$} \\
\hline \multicolumn{7}{|c|}{ Dukungan Keluarga } \\
\hline Baik & 22 & 75,9 & 7 & 24,1 & 29 & 100 \\
\hline Kurang Baik & 6 & 35,3 & 11 & 64,7 & 17 & 100 \\
\hline \multicolumn{7}{|c|}{$p$-value $=0,016 ;$ OR CI 95\% $=5,76$} \\
\hline \multicolumn{7}{|c|}{ Kepatuhan Program Terapi } \\
\hline Patuh & 20 & 76,9 & 6 & 23,1 & 26 & 100 \\
\hline Tidak Patuh & 8 & 40,0 & 12 & 60,0 & 20 & 100 \\
\hline
\end{tabular}

Hasil uji statistik didapatkan $\rho$ value $=0,013 \quad(\rho$-value $<0,05)$, berarti terdapat hubungan signifikan antara aktivitas fisik dengan kejadian rawat ulang pada pasien penyakit jantung koroner di RSUD dr. H. Abdoel Moeloek Provinsi Lampung Tahun 2016. Hasil analisis diperoleh nilai $O R=6,00$ (95\% CI: $1,63-22,03)$ berarti responden yang tidak melakukan aktivitas fisik berisiko untuk mengalami kejadian rawat ulang sebanyak 6,00 kali lebih besar dibandingkan responden yang melakukan aktivitas fisik.

Selanjutnya dari 30 responden yang patuh dalam dietnya, 22 responden $(73,3 \%)$ dirawat ulang untuk ke-2 kali dan 8 responden $(26,7 \%)$ dirawat ulang lebih dari 2 kali. Sedangkan dari 17 responden yang memiliki usia mendukung ada 4 responden $(23,5 \%)$ ambulasi dini tidak terlaksana dan 13 responden $(76,5 \%)$ ambulasi dini terlaksana.

Hasil uji statistik didapat $\rho$-value $=0,040$ $(\rho$-value $<0,05)$, berarti terdapat hubungan signifikan antara kepatuhan diet dengan kejadian rawat ulang pada pasien penyakit jantung koroner di RSUD dr. H. Abdoel Moeloek Provinsi Lampung Tahun 2016, dengan dengan nilai $O R=4,583 \quad(95 \% \quad$ CI: 1,25-16,75), berarti responden yang tidak mematuhi diet berisiko mengalami kejadian rawat ulang sebanyak 4,58 kali lebih besar dibandingkan dengan responden yang mematuhi diet.

Selanjutnya dari 29 responden yang memiliki dukungan keluarga baik, 22 responden $(75,9 \%)$ dirawat ulang ke-2 kali dan 7 responden
$(24,1 \%)$ dirawat ulang lebih dari 2 kali, sedangkan dari 17 responden yang memiliki dukungan keluarga kurang, 6 responden $(35,3 \%)$ dirawat ulang untuk ke-2 kali dan 11 responden $(64,7 \%)$ dirawat ulang lebih dari 2 kali.

Hasil uji statistik didapatkan $\rho$ value $=0,016 \quad(\rho$-value $<0,05)$, berarti terdapat hubungan signifikan antara dukungan keluarga dengan kejadian rawat ulang pada pasien penyakit jantung koroner di RSUD dr. H. Abdoel Moeloek Provinsi Lampung Tahun 2016, dengan nilai $O R=5,76$ (95\%CI: 1,557-21,328), berarti responden yang memiliki dukungan keluarga kurang, mempunyai peluang mengalami kejadian rawat ulang sebanyak 5,76 kali lebih besar dibandingkan responden yang memiliki dukungan keluarga baik.

Selanjutnya dari 26 responden yang patuh dalam program terapi, 20 responden $(76,9 \%)$ dirawat ulang untuk ke-2 kali dan 6 responden $(23,1 \%)$ dirawat ulang lebih dari 2 kali. Sedangkan dari 20 responden yang tidak patuh, terdapat 8 responden $(40,0 \%)$ dirawat ulang untuk yang ke-2 kali dan 12 responden $(60,0 \%)$ dirawat ulang lebih dari 2 kali.

Hasil uji statistik didapatkan $\rho$ value $=0,025 \quad(\rho$-value $<0,05)$, berarti terdapat hubungan signifikan antara kepatuhan program terapi dengan kejadian rawat ulang pada pasien penyakit jantung koroner di RSUD dr. H. Abdoel Moeloek Provinsi Lampung Tahun 2016, sedangkan nilai $O R=5,00$ (95\% CI:1,393-17,943) berarti responden yang tidak patuh dalam program terapi, mempunyai peluang mengalami kejadian rawat ulang sebanyak 5,00 kali lebih besar dibandingkan dengan responden yang patuh dalam program terapi.

\section{PEMBAHASAN}

\section{Kejadian Rawat Ulang}

Distribusi frekuensi kejadian rawat ulang yang ke-2 kali yaitu sebanyak 28 orang $(60,9 \%)$, sedangkan responden yang rawat ulang lebih dari 2 kali yaitu 18 orang $(39,1 \%)$. Hasil penelitian menunjukkan bahwa persentase responden dengan kejadian rawat ulang yang ke-2 kali pada pasien penyakit jantung koroner di ruang jantung RSUD dr. H. Abdoel Moeloek Provinsi Lampung lebih tinggi bila dibandingkan kejadian rawat ulang lebih dari 2 kali Hal ini menunjukkan bahwa rata-rata pasien penyakit jantung koroner di ruang jantung RSUD dr. H. Abdoel Moeloek Provinsi Lampung mengalami kejadian rawat ulang yang ke-2 kali. 


\section{Aktivitas Fisik}

Hasil analisa didapatkan $\rho$-value $=0,013$ yang berarti bahwa ada hubungan yang signifikan antara aktivitas fisik dengan kejadian rawat ulang pada pasien penyakit jantung koroner di ruang jantung RSUD dr. H. Abdoel Moeloek Provinsi Lampung Tahun 2016. Kemudian didapatkan $O R=6,00$ yang berarti bahwa responden yang tidak melakukan aktivitas fisik berisiko 6,00 kali lebih besar untuk mengalami kejadian rawat ulang bila dibandingkan dengan responden yang selalu melakukan aktivitas fisik.

Hasil penelitian didukung teori yang mengemukakan bahwa aktivitas fisik dapat menurunkan tonus saraf simpatik, mendorong penurunan berat badan dan meningkatkan metabolisme tubuh sehingga peredaran darah menjadi lebih lancar. Sejumlah penelitian epidemiologi mendukung hipotesis bahwa aktivitas fisik yang giat menurunkan resiko PJK. Aktivitas fisik (exercise) dapat meningkatkan kadar HDL kolesterol, memperbaiki kolteral koroner sehingga resiko PJK dapat dikurangi, memperbaiki fungsi paru dan pemberian oksigen ke miokard, menurunkan berat badan, menurunkan kolesterol, trigliserida dan tekanan darah (AHA, 2014).

Hasil penelitian ini didukung oleh penelitian Fatoni (2012) tentang faktor-faktor yang berhubungan dengan kejadian rawat inap ulang pada pasien PJK di RSUD Arifin Achmad Pekanbaru, didapatkan hasil ada hubungan antara kecukupan aktivitas dan istirahat $(p$-value $=0,030)$ dengan rawat inap ulang.

Menurut pendapat peneliti berdasarkan tabel 4.6 diketahui dari 27 responden yang melakukan aktivitas fisik ada 21 responden $(77,8 \%)$ mengalami kejadian rawat ulang yang ke-2 kali dan 6 responden $(22,2 \%)$ mengalami kejadian rawat ulang lebih dari 2 kali. Responden yang melakukan aktivitas fisik dan mengalami kejadian rawat ulang yang ke-2 hal ini mungkin didukung dengan faktor usia responden rata-rata dalam rentang usia dewasa tua belum masuk lanjut usia, sehingga mereka masih aktif dalam melakukan aktivitas fisik sehari-hari. Aktivitas fisik yang bersifat isometrik seperti jalan santai, renang, aerobik, bersepeda, jogging, pada pasien jntung koroner sangat penting karena mekanisme kerja otot pada saat melakukan aktivitas fisik dapat membantu menurunkan tekanan darah sistolik maupun diastolik. Adapun penurunan tekanan darah dapat menurunkan kerja jantung.

Selanjutnya dari 19 responden yang tidak melakukan aktivitas fisik ada 7 responden $(36,8 \%)$ mengalami kejadian rawat ulang yang ke-2 kali dan 12 responden $(63,2 \%)$ mengalami kejadian rawat ulang lebih dari 2 kali. Menurut pendapat peneliti responden yang tidak melakukan aktivitas fisik dan mengalami kejadian rawat ulang yang ke-2 kali, karena responden mematuhi diet yang dianjurkan, atau mematuhi program terapi yang telah ditentukan oleh dokter, karena banyak faktor yang dapat mempengaruhi kejadian rawat ulang lebih dari 2 kali pada pasien penyakit jantung koroner selain dari tidak melakukan aktivitas fisik.

\section{Hubungan Kepatuhan Diet dengan Kejadian Rawat Ulang}

Hasil analisa didapatkan $\rho$-value $=0,040$ yang berarti bahwa ada hubungan yang signifikan antara kepatuhan diet dengan kejadian rawat ulang pada pasien penyakit jantung koroner di ruang jantung RSUD dr. H. Abdoel Moeloek Provinsi Lampung Tahun 2016. Kemudian didapatkan $O R=4,58$ yang berarti bahwa responden yang tidak mematuhi diet berisiko sebanyak 4,58 kali lebih besar untuk mengalami kejadian rawat ulang bila dibandingkan dengan responden yang selalu melakukan mematuhi diet yang dianjurkan.

Hal ini didukung teori yang dikemukakan oleh Smeltzer \& Bare (2012) bahwa salah satu faktor terjadinya rawat inap ulang pasien penyakit jantung koroner adalah tidak patuh atau melanggar pembatasan diet. Manajemen nutrisi pada pasien penyakit jantung koroner adalah untuk mengurangi natrium dan retensi cairan.

Hasil penelitian ini sejalan dengan penelitian Abdul Majid (2010) tentang analisis faktor-faktor yang berhubungan dengan kejadian rawat inap ulang pasien gagal jantung koroner di Rumah Sakit Yogyakarta, didapatkan hasil ada hubungan antara kepatuhan terhadap diet ( $p$ value $=0,008)$ dengan kejadian rawat inap ulang pasien PJK.

Menurut peneliti berdasarkan tabel 4.7 diketahui dari 30 responden yang mematuhi diet ada 22 responden $(73,3 \%)$ mengalami kejadian rawat ulang yang ke-2 kali dan 8 responden $(26,7 \%)$ mengalami kejadian rawat ulang lebih dari 2 kali. Responden yang mematuhi diet dan mengalami kejadian rawat ulang yang ke-2 kali mungkin karena responden mematuhi diet yang dianjurkan dengan cara makan makanan rendah garam, rendah lemak dan kaya serat, banyak makan sayuran hijau dan buah segar. Menghindari makanan yang mengandung kolesterol seperti cumi, udang, kepiting, otak sapi, daging kambing, daging berlemak, organ dalam hewan/ jeroan, bebek, belut, kuning telur, 
susu sapi, kulit ayam, makanan kemasan olahan daging ayam.

Selanjutnya dari 16 responden yang tidak mematuhi diet ada 6 responden $(37,5 \%)$ mengalami kejadian rawat ulang yang ke-2 kali dan 10 responden $(62,5 \%)$ mengalami kejadian rawat ulang lebih dari 2 kali. Menurut pendapat peneliti responden yang tidak mematuhi diet dan mengalami kejadian rawat ulang yang ke-2 kali hal ini terjadi mungkin responden selalu olahraga secara rutin, meluangkan banyak waktu untuk istirahat dan menghindari stres, serta mungkin mendapatkan dukungan yang positif dari keluarga.

\section{Hubungan Dukungan Keluarga dengan Kejadian Rawat Ulang}

Hasil analisa didapatkan $\rho$-value $=0,016$ yang berarti bahwa ada hubungan yang signifikan antara dukungan keluarga dengan kejadian rawat ulang pada pasien penyakit jantung koroner di ruang jantung RSUD dr. H. Abdoel Moeloek Provinsi Lampung Tahun 2016. Kemudian didapatkan $O R=5,76$ yang berarti bahwa responden dengan dukungan keluarga kurang berisiko sebanyak 5,76 kali lebih besar untuk mengalami kejadian rawat ulang bila dibandingkan dengan responden yang memiliki dukungan keluarga baik.

Hasil penelitian didukung teori Niven (2002) dukungan keluarga dapat membantu meningkatkan mekanisme koping individu dengan memberikan dukungan emosi dan saransaran mengenai strategi alternatif yang didasarkan pada pengalaman sebelumnya dan mengajak orang lain berfokus pada aspek-aspek yang lebih positif. Selain mendapat dukungan dari keluarga, pasien penyakit jantung koroner yang mengalami kecemasan sedang juga melakukan pendekatan religius dengan cara berdzikir, berdo'a sesuai dengan keyakinan masing-masing.

Hasil penelitian ini didukung oleh penelitian Abdul Majid (2010) tentang analisis faktor-faktor yang berhubungan dengan kejadian rawat inap ulang pasien gagal jantung koroner di Rumah Sakit Yogyakarta, didapatkan hasil ada hubungan antara dukungan keluarga dan sosial ( $p$-value $=0,028)$ dengan kejadian rawat inap ulang pasien PJK.

Menurut pendapat peneliti berdasarkan tabel 4.8 diketahui bahwa dari 29 responden yang memiliki dukungan keluarga baik ada 22 responden $(75,9 \%)$ mengalami kejadian rawat ulang yang ke-2 kali dan 7 responden $(24,1 \%)$ mengalami kejadian rawat ulang lebih dari 2 kali.
Responden yang memiliki dukungan keluarga baik, hal ini akan membuat responden merasa nyaman, aman, merasa selalu didengar dan diterima setiap masalah-masalahnya, tidak merasa sendiri hal tersebut akan mendukung baik fisik, mental maupun spiritual pasien. Hal ini dapat menurunkan kemungkinan terjadinya rawat ulang yang lebih dari 2 kali pada pasien dengan penyakit jantung koroner.

Selanjutnya dari 17 responden yang kurang mendapat dukungan keluarga ada 6 responden $(35,3 \%)$ mengalami kejadian rawat ulang yang ke-2 kali dan 11 responden $(64,7 \%)$ mengalami kejadian rawat ulang lebih dari 2 kali. Menurut peneliti responden yang kurang mendapat dukungan keluarga tetapi mengalami kejadian rawat ulang yang ke-2 kali ini mungkin karena responden selalu mematuhi diet yang dianjurkan, minum obat secara teratur, selalu rutin berolahraga serta melakukan aktivitas sehari-hari.

\section{Hubungan Kepatuhan Program Terapi dengan Kejadian Rawat Ulang}

Hasil analisa didapatkan $\rho$-value $=0,025$ yang berarti bahwa ada hubungan yang signifikan antara kepatuhan program terapi dengan kejadian rawat ulang pada pasien penyakit jantung koroner di ruang jantung RSUD dr. H. Abdoel Moeloek Provinsi Lampung Tahun 2016. Kemudian didapatkan $O R=5,00$ yang berarti bahwa responden yang tidak patuh terhadap program terapi berisiko sebanyak 5,00 kali lebih besar untuk mengalami kejadian rawat ulang bila dibandingkan dengan responden yang patuh terhadap program terapi.

Menurut Smeltzer \& Bare (2012) kekambuhan penyakit jantung koroner dan dirawat kembali di rumah sakit terjadi karena pasien tidak memenuhi terapi yang dianjurkan dan terapi pengobatan kurang tepat. Kepatuhan terhadap terapi medis harus ditanamkan kepada pasien dengan penyakit jantung koroner. Ketidakpatuhan meningkatkan mortalitas, morbiditas dan perawatan dirumah sakit.

Hasil penelitian ini sejalan dengan penelitian Fatoni (2012) tentang faktor-faktor yang berhubungan dengan kejadian rawat inap ulang pada pasien PJK di RSUD Arifin Achmad Pekanbaru, didapatkan hasil ada hubungan antara kepatuhan terapi pengobatan $(p$-value $=0,014)$ dengan rawat inap ulang.

Menurut pendapat peneliti berdasarkan tabel 4.9 diketahui bahwa dari 26 responden yang patuh terhadap program terapi ada 20 responden $(76,9 \%)$ mengalami kejadian rawat ulang yang ke-2 kali dan 6 responden $(23,1 \%)$ mengalami 
kejadian rawat ulang lebih dari 2 kali. Peneliti berpendapat jika pasien mematuhi tindakan atau terapi yang telah ditentukan maka penyakit itu dapat dikendalikan atau dikontrol sehingga akan mengurangi resiko kejadian rawat ulang.

Selanjutnya dari 20 responden yang tidakmematuhi program terapi ada 8 responden $(40,0 \%)$ mengalami kejadian rawat ulang yang ke-2 kali dan 12 responden $(60,0 \%)$ mengalami kejadian rawat ulang lebih dari 2 kali. Menurut pendapat peneliti responden yang tidak mematuhi program terapi dan mengalami kejadian rawat ulang yang ke-2 kali hal ini mungkin memiliki perilaku sehat dalam kehidupan sehari-hari seperti mengkonsumsi makanan rendah lemak, rendah garam, banyak makan sayuran dan buah segar, olahraga secara teratur, menghindari stres dan istirahat yang cukup, sehingga hal ini akan mencegah kekambuhan pasien untuk kejadian rawat ulang.

\section{DAFTAR PUSTAKA}

American Heart Association. 2014. Evaluation and Management of Coronary Heart Disease in the Adult. Available from: http://circ.ahajournals.org/content/104 /24/2996.full.pdf (Diakses tanggal 10 Maret 2016).

Fatoni. 2012. Faktor-faktor yang Berhubungan dengan Kejadian Rawat Inap Ulang pada Pasien PJK di RSUD Arifin Achmad Pekanbaru. http://www.fatoni. online.com (Diakses pada tanggal 10 Maret 2016).

\section{SIMPULAN}

Berdasarkan hasil penelitian dan pembahasan, disimpulkan pasien penyakit jantung di Ruang Jantung RSUD dr. H. Abdoel Moeloek Provinsi Lampung Tahun 2016:

1. Sebagian besar $(58,7 \%)$ melakukan aktivitas fisik, $(65,0 \%)$ patuh menjalani diet, $63,0 \%$ memiliki dukungan keluarga yang baik, Sebagian besar patuh menjalankan program terapi $(56,5 \%)$, dan $60,9 \%$ mengalami kejadian rawat ulang yang ke-2 kali.

2. Ada hubungan antara aktivitas fisik dengan Kejadian rawat ulang pada pasien penyakit jantung koroner ( $p$-value $=0,013$ ).

3. Ada hubungan antara kepatuhan diet dengan Kejadian rawat ulang pada pasien penyakit jantung koroner $(p$-value $=0,040)$.

4. Ada hubungan antara dukungan keluarga dengan Kejadian rawat ulang pada pasien penyakit jantung koroner ( $p$-value $=0,016$ ).

5. Ada hubungan antara kepatuhan program terapi dengan Kejadian rawat ulang pada pasien penyakit jantung koroner ( $p$ value $=0,025$ ).

Majid, A. 2010. Analisis faktor faktor yangberhubungan dengan kejadian rawat inap ulang pasien gagal jantung koroner di rumah sakit Yogyakarta tahun 2010. Dalam lontar.ui.ac.id/file?file=digital/ 20281141T\%20Abdul\%20 Majid.pdf (Diakses tanggal 12 Maret 2016).

Niven. N. 2002. Psikologi Kesehatan Pengantar untuk Perawat dan Profesional Kesehatan Lain. Edisi Kedua. Jakarta: EGC.

Smeltzer, S. C. \& Bare, B. G. 2012. Keperawatan Medikal-Bedah. Jakarta: EGC. 